Dina Emundts (Ed.)

Self, World, and Art 



\section{Self, World, and Art}

Metaphysical Topics in Kant and Hegel

Edited by

Dina Emundts

\section{DE GRUYTER}


Printed with the financial support of the Thyssen-Stiftung, Cologne.

ISBN 978-3-11-029078-3

e-ISBN 978-3-11-029081-3

Library of Congress Cataloging-in-Publication Data

A CIP catalog record for this book has been applied for at the Library of Congress.

Bibliographic information published by the Deutsche Nationalbibliothek

The Deutsche Nationalbibliothek lists this publication in the Deutsche

Nationalbibliografie; detailed bibliographic data are available in the Internet at http://dnb.dnb.de.

(c) 2013 Walter de Gruyter GmbH, Berlin/Boston

Typesetting: Anne Mone Sahnwaldt, Konstanz

Printing: Hubert \& Co. GmbH \& Co. KG, Göttingen

(2) Printed on acid-free paper

Printed in Germany

www.degruyter.com 
For Rolf Horstmann 
